\title{
Sedimentology of South-East Singkarak Lakes : Case Study From Modern Sediment in Fluvio-Lacustrine Depositional Environment
}

\author{
Said Muzambiq*, Zaka L. Tarigan** \\ *Geology Department, Institut Teknologi Medan (ITM) Medan, Indonesia \\ **Independent Geologist
}

\section{Abstract}

Singarak lake is third biggest lakes in Sumatra and largest lake formed by tectonical pull apart of Great Sumatran Fault System. In modern days, Singkarak lakes is considered to be a most complete in sedimentation process with various of sediment depositional environment.

This reseach focused to sedimentological character and hydrodynamics of Sumani River area, a main inlet system and South-East area coastal of Singkarak lake. The study objective is basic sedimentological research to determine sediment character and depositional environment based on field activity which is divided into 3 (three) types that is taking the core of sediment by PVC Coring method, outcrop observation and modern sediment analysis.

In South-East area of Singkarak lake and Sumani River classified three types of depositional environment with different character of sedimentology and hydrodynamics which is Meandering River Fluvial of Sumani River, Lacustrine Backshore of South-East Singkarak lake and Foreshore of South-East Singkarak lake. Determination is based on sediment grain size, sedimentary structure, content of sediment and also modern morphology of each condition.

Keywords: Lacustrine Sedimentology, Singkarak Lake, Depositional Environment, Hydrodynamics

\section{Introduction}

Lake Singkarak (Indonesian: Danau Singkarak) is a lake in West Sumatra, Indonesia. It is located between the cities of Padang Panjang and Solok. It has an area of $107.8 \mathrm{~km}^{2}$, being approximately $21 \mathrm{~km}$ long and $7 \mathrm{~km}$ wide. The natural outlet for excess water is the Ombilin river which flows eastward to the Strait of Malacca (Wikipedia, 2017).

\section{Singkarak Basin Deformation and Tectonic Setting}

Lake Singkarak is the largest modern-day pull-apart basin in Indonesia. The Lake was formed by active trans-tensional tectonic regime at one of many components of the Great Sumatera Fault, and was formed by a strike-slip fault system of pull apart basin between Sumani segment in the SE and Sumpur in the NW (figure 1).

\section{Singkarak Lake Depositional Environment Model}

Sedimentation rate of his lake is $14 \mathrm{~cm} /$ year. Its fluvio-lacustrine depositional system can be divided into nine parts 1)fluvial-meandering channel complex, 2)fluvial-braided complex, 3)fan delta, 4)lacustrine delta, 5)shoreline lacustrine, 6)shallow lacustrine, 7)deep-lacustrine pelagic facies, 8) deep-lacustrine channel and levee complex, 9)deep-lacustrine fan. The $72 \%$ of the modern-day Lake Singkarak's total area (rift-climax condition) is dominated by 
shallow to deep lacustrine (distal facies), while the remaining $28 \%$ is covered by the fluvial to transitional-lacustrine sediments (Setyobudi and Tarigan, 2016).

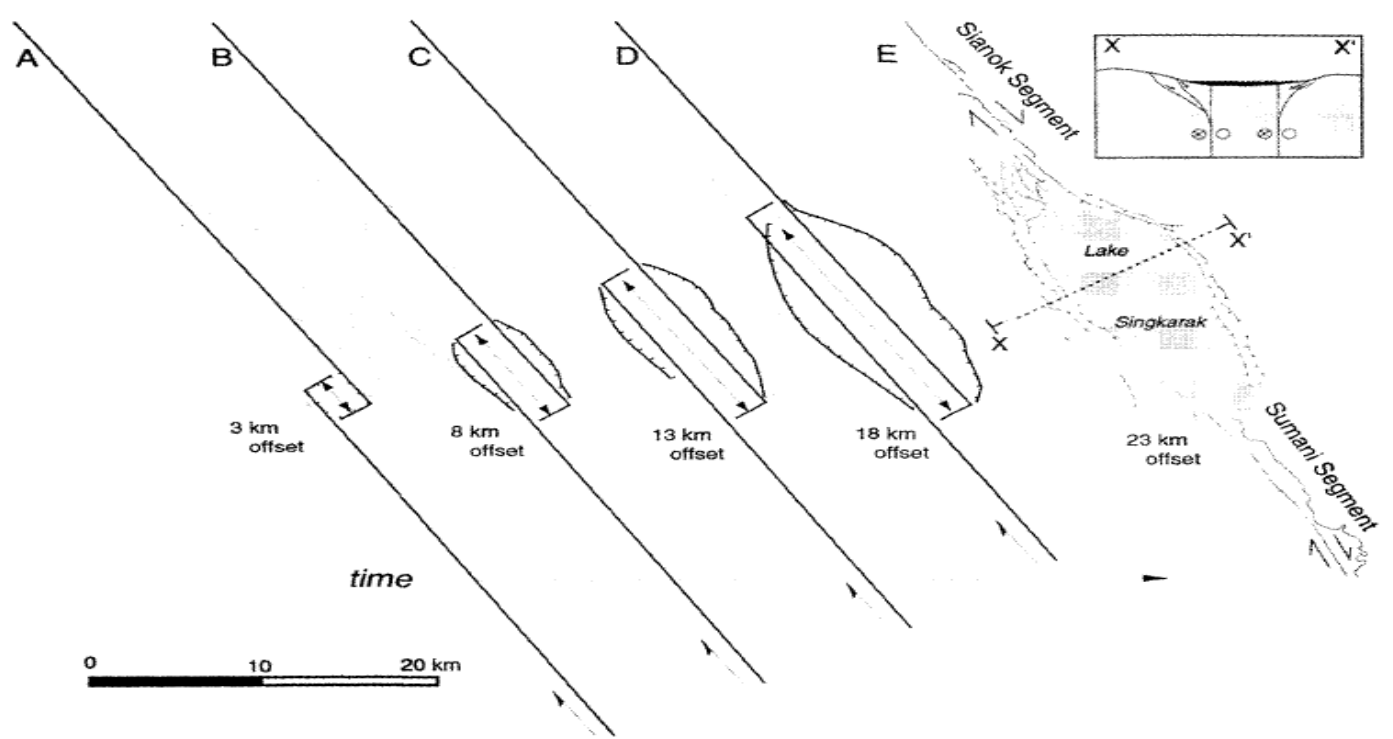

Figure 1. Hypotetical evolution of the Singarak graben and bounding normal faults

(Natawidjaja, 2000).

\section{Data and Methodology}

In this research, data collecting activity is done by conducting main field activity which is divided into 3 (three) types that is taking the core of sediment by PVC Coring method, outcrop analysis and modern sediment condition of Singkarak lake. In addition, river basin observation activities, observation outcrops, and morphological observations to determine the geological conditions of the lake area and surrounding Singkarak.

Data collection is focused on Sumani area, South-East part of Lake Singkarak with total 7 points of observation covering meandering river, point bar, lacustrine shore line and shallow lacustrine.

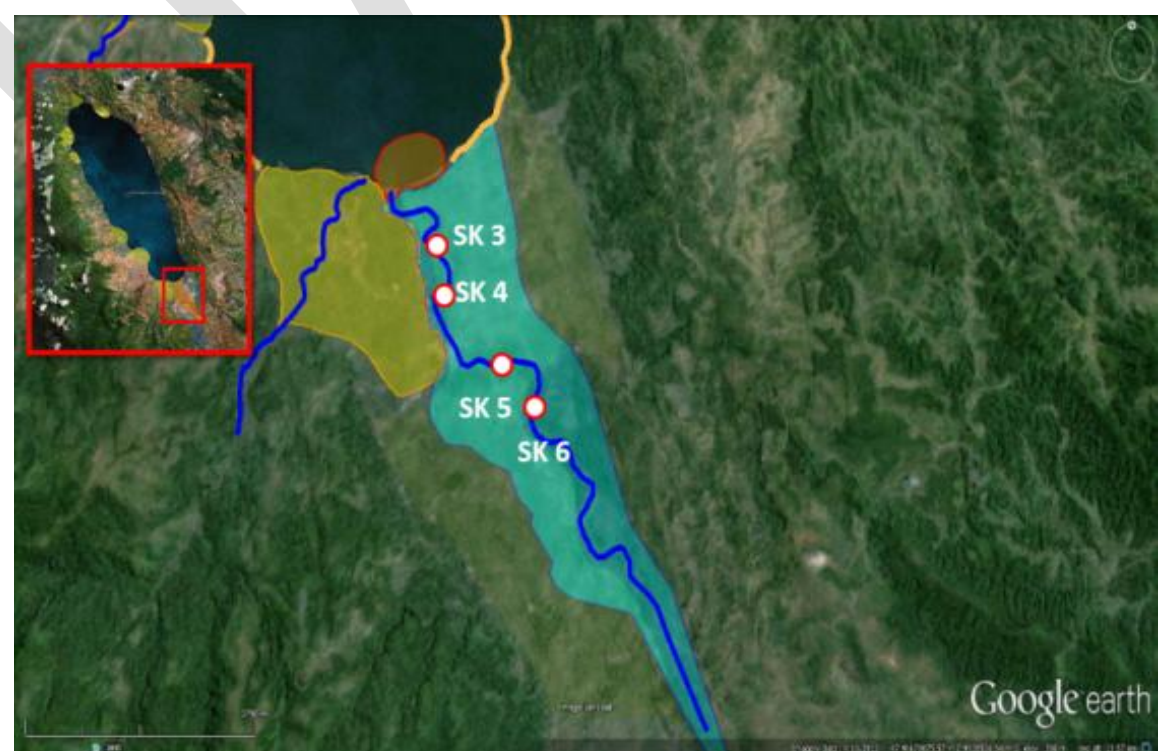

Figure 2. Satellite Imagery of Sumani River and Location of Sediment Sampling 


\section{Sedimentology of South-East Singkarak lake SumaniFluvio-Lacustrine}

In freshwater lake environment such as Singkarak lake, the influence of fluvial or river system is very big. The supply of water entering the lake and out of the lake in an open lake is very influential, not only on the hydrological system but also on the sediment deposition conditions in the lake environment.

This research is focused to identify sedimentological character (sediment character and hydrodynamics) of Fluvio-Lacustrine sediment deposition environment in Sumani area, along Sumaniriver to South-Eastern part of Singkarak Lake (figure 2).

\section{a. SumaniRiver Fluvial(Meandering River)}

In the meandering river environment, the sedimentation process occurs in the river and surrounding areas that are still affected by the movement of river currents. Sedimentation process is very active which then produce sediment sediment with varied facies.

At the location of SK-6, Sumani river can be seen sedimentation process that occurs on the meandering river. Based on the core analysis by making the river morphology crossing can be observed sediment sediment in the river environment. Sediments deposited on the river side are dominated by sand-sized sediments with some sedimentary stumps that are the result of sediment at the time of flooding. In the natural levee can be found sediments of rough-sized sand to clay which is a sediment flood plain. On the river bank found sedimentsized sediment which is the result of flash flood sediment (figure 3).

At the location of SK-6 also found sediment outcrop in the deposition environment ofriver meandering.Berdasarkan sediment found on the location of SK-6 found 3 sediment facies. At the bottom layer found sediment with silt grain size, no sedimentary structure and little organic material content. In general, sediments with fine grain size such as silt will only be deposited under weak traction current conditions or joint suspension. In the meander river system conditions that can produce a silt-sized sedan facies are on the flood plain and oxbow parts, but since the Sumani river does not have oxbow, it is interpreted that the facies are the result of flood plain deposits.

The next layer is the fascination of the conglomerate of the sand. Rough-sized sediment deposits will only be precipitated by traction currents strong enough to transport rough-sized sediments and in this case traction and turbidity currents. Based on surface observations that are also part of the point bar of the Sumani river, the facies are interpreted to be deposited on the point bar with fragmented fragments carried by the flood currents forming turbidite currents, it is also supported by the axis alignment or imbrication of the fragments (figure 4). Then the last facies are fine sand-sized sediments with good sorting and no structural or other sedimentary structures are found. The sand-sized sediment is generally transported by traction currents and by looking at the sorting and grain size of the sediments in the facies, it is known that the sediment is deposited under stable conditions such as the channel portion of a meandering river system.

Another part of the Sumani river that shows sedimentation occurring in the meandering river deposition environment can be seen at the location of SK-3. Based on morphological observation, the location of SK-3 is a point bar of the Sumani river seen from its condition which is located on river curve with sediment oriented towards the smooth flow of river (AA").

The PVC Core results taken at the SK-3 site also explain the sediment character deposited in the river environment. Sediment composition dominated by sand-sized sediment with several layers has an upward gradient orientation indicating a sedimentation process that takes place in the river body while a layer with an upward-oriented orientation indicates the deposition process taking place at the river's point bar. The boundary between layers in the 
field of erosion explains that the sedimentation process is active and in certain conditions changes can occur that cause changes in sediment character (figure 5).

\section{- Hydrodynamics}

Based on the character of the sediment in the observation location and the sediment samples obtained on the Sumani river flow provide an overview of the sedimentation process that occurs in the meandering river environment. The hydrodynamic conditions affecting the sedimentation process in this sedimentary environment are generally influenced by the flow of river flows into the lake with the type of traction current.
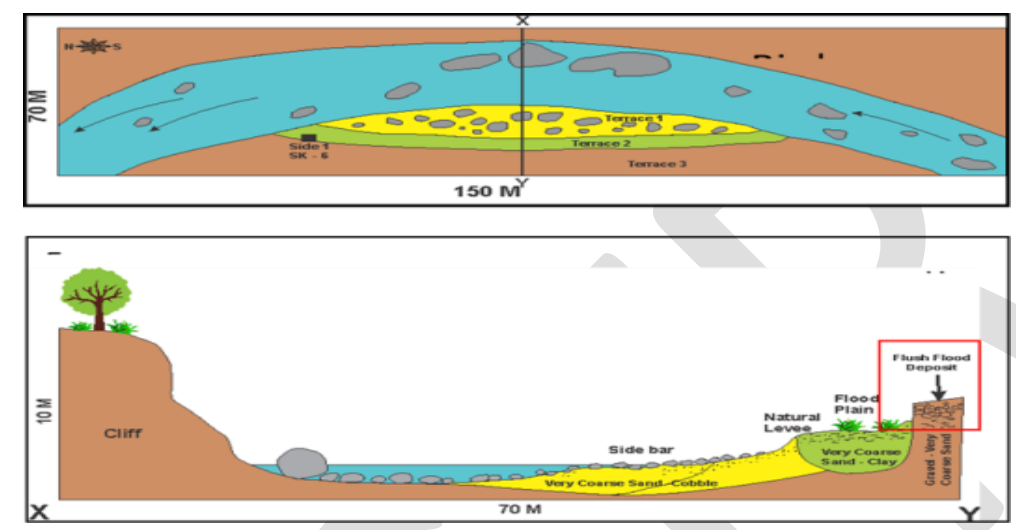

Figure 3. Sketches and Morphological Sections of Sumani River At Location SK-6

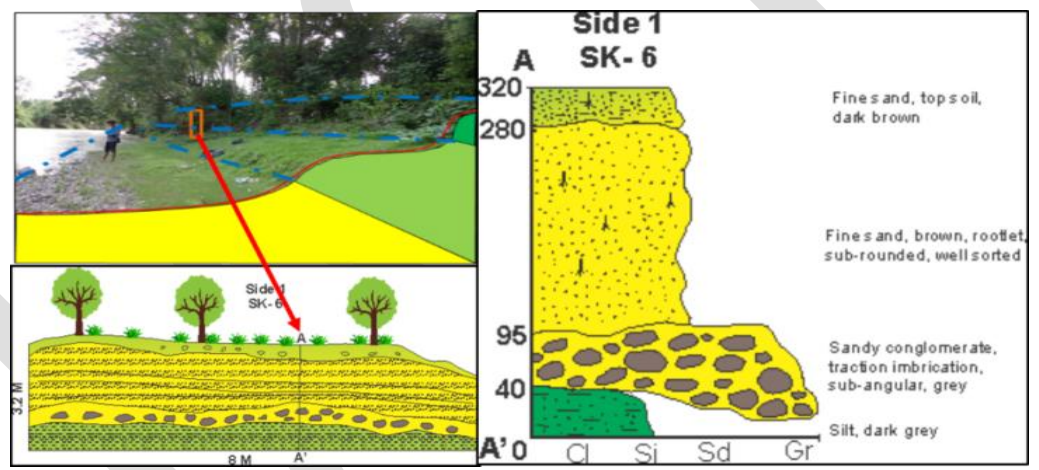

Figure 4. Sediment Outline Sketch on Meandering River System of Sumani River and

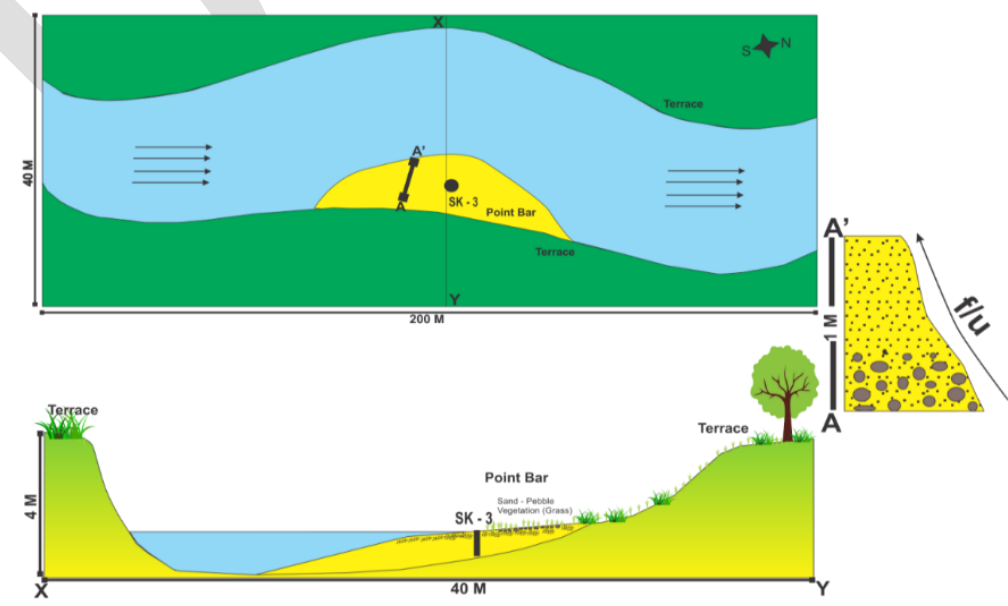

Stratigraphic Section Location SK-6

Figure 5. Sketch Point Bar on Meandering River System Location SK-3, Sumani River 
In some conditions such as those at SK-6 where roughly-sized sediments are found that are not transported at normal times, they will only be transported under flood conditions where current flows have considerable strength or may be transformed into turbidite currents under banjir bandang conditions. The fine-sized sediments deposited above normal water level conditions are sediments deposited in suspension conditions derived from the remnants of the flooding process.

The process that occurs at the location of SK-3 can be explained by the concept of hydrodnamic where on the bend of the river there will be scour zone on the outside and the accumulation on the inside which then form the point bar.

\section{b. South-East SingkarakShoreline Complex}

In general, the beach complex on the lake Singkarak divided into 2, namely the back of the coastline (backshore) and front of the coastline (foreshore) (figure 6).

\section{Backshore}

The backshore section is part of the beach that is not exposed to the waves at the time the normal waves work, but at certain times where the power of the waves is larger as the time of the storm, this section will experience a sedimentation process eroded by waves coming from the shore.

\section{- Sediment Character}

In the backshore section, in the sample of PVC Core at SK-1 location, 2 sedimentary facies were found, sand facies with crude fragments and oxidized clay facies. Sand facies indicate the normal deposition conditions that are in the coastal system with sediments that are transported by waves in the lake Singkarak. The oxidized clay facies indicate that after the facies are formed then undergo lifting so that there is oxidation by the surrounding air. Based on the content of the existing fragments, it is interpreted that the facies are deposited in quieter environments such as shallow lakes or swamps (figure 7).

\section{- Hydrodynamics}

Hydrodynamic conditions in the coastal deposition environment on the backshore are strongly influenced by the movement of wave activity formed in Singkarak lake. Activity of the movement of the wave formed in the form of traction that transports the sediment on the bottom of the lake and transport to the edge of the beach and erode the rocks located around the coastal lakes.

\section{Foreshore}

The foreshore part is the part that is always under water. Generally has a depth of up to 2 meters below the surface of the lake water. In this section, the sedimentation process will be controlled by the movement of water waves that drain traction currents and at times when the waves are smaller, sedimentation will occur with the decrease of the suspension which is a fine-sized sediment such as clay and silt (figure 8).

\section{- Sediment Character}

In the foreshore section of PVC Core samples at SK-2 site 3 different facies were found, carbonaceous clay facies, clay sediment facies and sand sediment facies. The carbonaceous clay facies found in inner core layers in coastal environments show ideal conditions for organism life, especially the molluscs that form coquina beds, where the hydrodynamic conditions tend to be calm, thus precipitating suspended sediments such as clay and silt. The clay sediment facies obtained in the foreshore environment show that the effect of traction 
currents arising from the movement of surface waves does not have a major impact on sediment deposition by precipitating only the fine sediments.

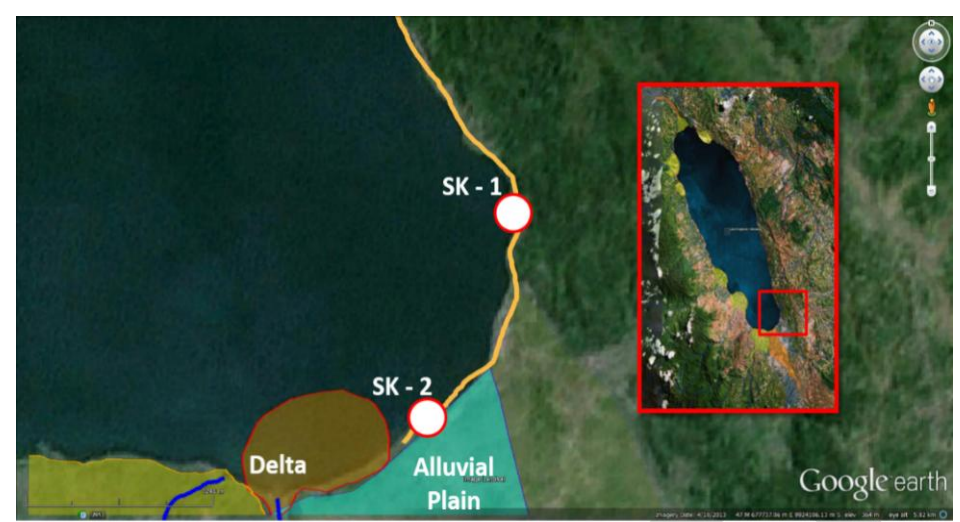

Figure 6. Satellite Images of Singkarak and Location SK-1 and SK-2 Shows East Singkarak Lake Beach Lines

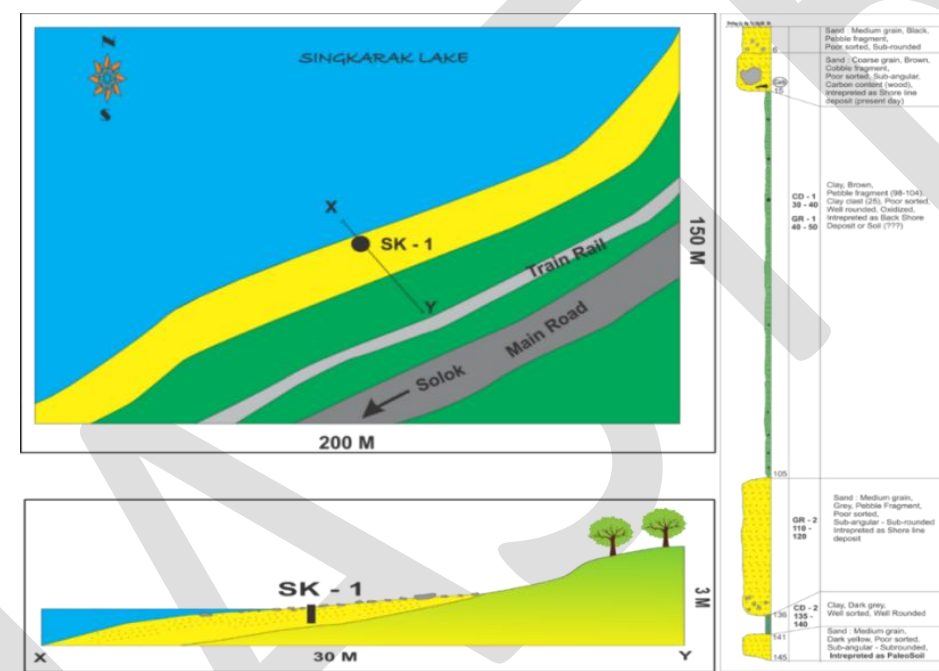

Figure 7. Morphology Sketch, Morphological Section and Stratigrafi SK-1

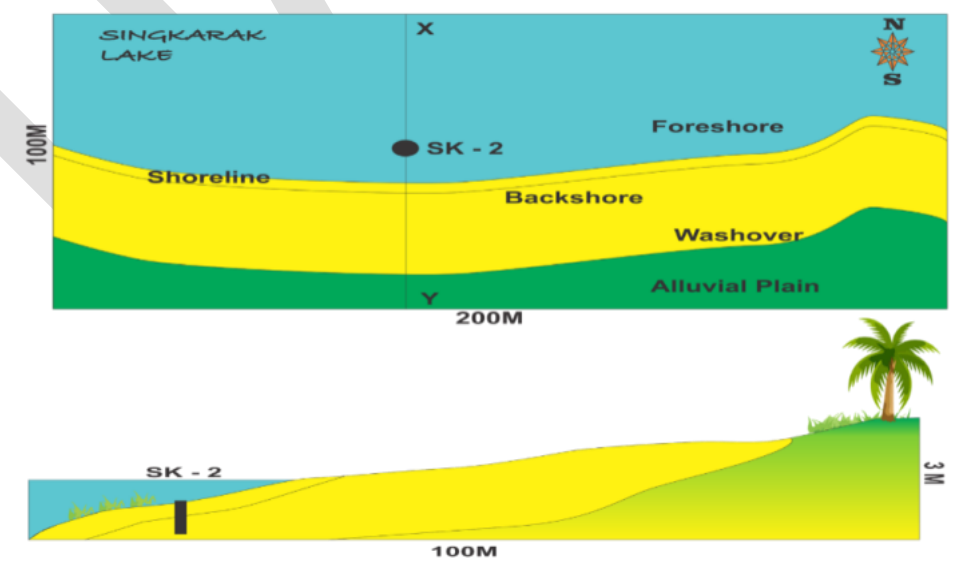

Figure 8. Satellite Images of Singkarak and Location SK-1 and SK-2 Shows East Singkarak Lake Beach Lines

The sand sediment facies found on cores in the foreshore section explain that during certain periods of natural conditions, sediments deposited may be sediments that require 
traction currents such as sand can also settle in parts of the shoreline complex such as during storms or seasons Drought that causes the volume of lake water to decline (figure 9).

\section{- Hydrodynamics}

Hydrodynamic conditions in the foreshore coastal deposition environment are strongly influenced by the movement of wave activity formed in Singkarak. Waves that are only driven by the wind are only capable of moving sediment in the shallow part. Hence, the hydrodynamic conditions that occur are dominated by sediment suspensions that produce fine-sized sediments on the foreshore section.

\section{Conclusion}

Based on field data acquisition by PVC Cores, outcrop observation and modern sediment analysis based on outcrop and surface sediment in Sumani River and South-East Singkarak area, can be detemined 3 types of sediment depositional environtment by each sedimentology and hydrodynamics character.

1. Meandering River Fluvial in Sumani River area.

2. Lacustrine Backshore in South-East Singkarak Lake area.

3. Lacustrne Foreshore in South-East Singkarak Lake area.

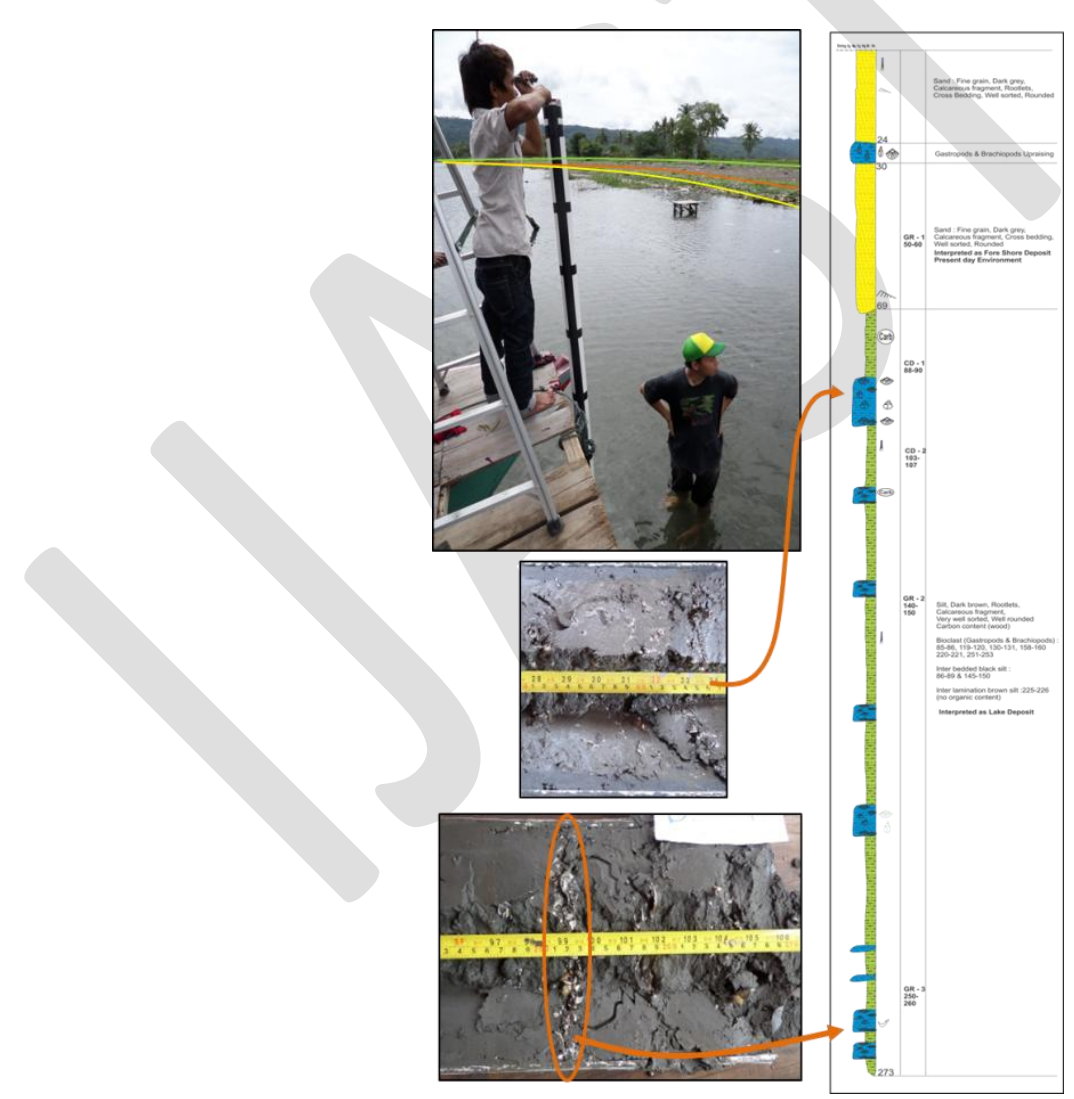

Figure 9. Location SK-2 and PVC Core Results On Foreshore Environment.

\section{References}

- Bachtiar, A., Suandhi, P.A., Tarigan, Z.L., 2015, "Sedimentology of Modern Tropical Rift Basin of Lake Singkarak : Analog Model for Central Sumatra and Ombilin 
Basins, Sumatra, Indonesia”, AAPG-SEG International Conference and Exhibition 2015, Melbourne, Australia.

- Barber, A.J., M.J. Crow \& J.S. Milsom. 2005, "Sumatra: Geology, Resources and Tectonic Evolution". GeolSoc., London, Mem. 31.

- Mulyana, H., dan Moechtar, H., 2010, "Penarikhan Radiokarbon Kaitannya dengan Dinamika Daur Proses Pengendapan Kuarter Fluvial dan Danau Terhadap Perubahan Iklim dan Tektonik di Paparan Danau Singkarak, Kab. Solok, Sumatra Barat", Bulletin of Scientific Contribution, 8, $29-40$.

- Natawidjaja, D.H., 2002, "Neotectonics of the Sumatra Fault and Paleogeodesy of the Sumatra Subduction Zone", California Institute of Tecnology, California, Doctoral Thesis : Unpublished.

- Puslit-Limnologi., 2009, "Peta Bathimetri Danau Singkarak", in Emelia, Fitri.2009. "Alternatif Pemanfaatan Danau bagi Pengembangan Wisata Melalui Konsep Keberlanjutan Sumberdaya Perairan dan Perikanan di Danau Singkarak, Sumatra Barat", Institut Pertanian Bogor. Skripsi; Unpublished.

- Setiobudi, P.T., Tarigan, Z.L., 2016, "Sedimentology And Limnology Of Singkarak And Toba Lakes, Sumatra, Indonesia: Depositional And Petroleum System Model For Tropical Fluvio-Lacustrine And Volcanic Related Rift Basins In Southeast Asia", Indonesian Petroleum Association : Proceedings IPA16-660-G.

- Zaka L. Tarigan, 2014, "Studi Sedimentologi Danau Di Danau Singkarak, Kabupaten Tanah Datar dan Solok Propinsi Sumatera Barat, Indonesia", Institut Teknologi Medan : Internal Published, Medan - Indonesia. 